\title{
LA FILOSOFÍA EN LAS ARTES ESCÉNICAS DEL SIGLO XXI
}

\author{
Susana M. Teruel Martínez \\ IES Gil de Junterón (Beniel,Murcia)
}

\begin{abstract}
Desde sus orígenes hasta hoy día, el teatro representa la vida, los problemas que preocupan al ser humano en su existencia, la felicidad, la alegría, el dolor o la tristeza de hombres y mujeres en la sociedad. El teatro transmite emociones a los espectadores, que pueden sentirse identificados con los sentimientos, con las acciones y con los personajes que aparecen en escena. Por eso, el arte dramático es algo más que entretener a un público, pues su esencia va más allá, al reflejar y transferir valores, modelos de conducta y emociones.

En este sentido, la filosofía y el teatro mantienen una estrecha relación, que debemos resaltar especialmente en la actualidad, como muy bien se aprecia en el libro Teatro y Filosofia en los inicios del siglo XXI ${ }^{1}$, que recoge veinticinco estudios de dramaturgos e investigadores prestigiosos que analizan esta conexión y sus experiencias en la escena contemporánea. Este volumen pertenece al célebre Centro de Investigación de Semiótica Literaria, Teatral y Nuevas Tecnologías, dirigido por José Romera Castillo, Catedrático Emérito de Literatura Española de la UNED. Asimismo, constituye la vigésimo octava edición de los seminarios internacionales de investigación de semiótica literaria, teatral y nuevas tecnologías de la UNED, cuyas líneas de indagación sobre teatro, literatura y cine de los siglos $X X$ y $X X I$, y sus 29 números de la famosa revista Signa dan muestra de su gran tradición e interés en el estudio de las innovaciones más recientes en este campo.

Tras una presentación realizada por don José Romera Castillo, en la que expone las diferentes y apasionantes investigaciones que SELITEN@T ha llevado a cabo sobre el teatro más actual y sus conexiones con otras artes, los numerosos y acreditados seminarios internacionales realizados o las ediciones de sus revistas, encontramos cuatro magníficos apartados: «Aspectos generales», «Dramaturgias femeninas», «Dramaturgias masculinas» y «Publicaciones del Centro de Investigación de Semiótica Literaria, Teatral y Nuevas Tecnologías» (en el que se aprecia la intensa labor académica y científica desempeñada por SELITEN@T).
\end{abstract}

\footnotetext{
${ }^{1}$ José Romera Castillo (ed.), Teatro y Filosofía en los inicios del siglo XXI, Verbum, Madrid, 2019.
} 
En «Aspectos generales», podemos leer diez artículos, en los que la filosofía forma parte de las puestas en escena de diversas obras dramáticas. Jerónimo López Mozo, en «La filosofía entre tablas y diablas en el siglo XXI», hace un recorrido por el teatro español de nuestro siglo, analizando aquellos textos y espectáculos en los que la filosofía está presente, tales como Himmelweg (Camino del cielo), de Mayorga, o Demasiado humano (los últimos días de Nietzsche), de Jaime Romo, entre otros. Emeterio Díez, Jorge Dubatti y Jorge Eines nos invitan a una reflexión sobre la filosofía de la praxis teatral, el papel del artista e investigador o sobre la palabra en «Filosofía de la praxis teatral». Además, Jorge Dubatti nos cuenta tres historias suyas para responder a varias cuestiones sobre la Filosofía del teatro en su estudio «La filosofía del teatro como construcción científica: qué, por qué, para qué».

En «El teatro y la razón poética», José Luis Alonso de Santos habla de la Razón poética, pues es lo que sustenta su creación, ya que los escritores transitan dos mundos y es muy importante esa "visión artística de la vida» que transmiten a su público. En «La ceguera del dramaturgo», Raúl Hernández revisa el grado de visión y conciencia que tiene el dramaturgo, el cual necesita la ceguera para explorar el texto teatral. En «La filosofía de Baltasar Gracián en la adaptación teatral de El Criticón de la compañía Teatro del Temple», Jesús Ángel Arcega Morales comenta la versión escénica que ha realizado la compañía Teatro del Temple sobre El Criticón, de Gracián, en la que se transmiten unas ideas filosóficas muy acordes con la crisis y el pesimismo que se palpa en nuestro siglo.

La importancia de filósofos como Nietzsche, Platón o San Agustín en el teatro se estudia también en este apartado. Diego Sánchez Meca, en «Teatro y filosofía de Friedrich Nietzsche», nos demuestra la raíz nietzscheana que existe en muchos dramas actuales, así como la trascendencia de este filósofo, que fue un crítico apasionado de las artes escénicas. En «La idea en escena: Platón, San Agustín y Spinoza», Marta J. Ortega Máñez indica que la filosofía sube al escenario, pues se han realizado montajes de textos de San Agustín, de Spinoza o de Platón en la actualidad, como los confeccionados por Guénoun.

Cierran este apartado primero dos artículos en los que se habla de la Fenomenología teatral, tan vinculada a la experiencia del ser humano. En «El teatro teatra. Problemas de fenomenología teatral», Gemma Pimenta Soto propone una relectura de algunas obras teatrales a la luz de fenomenología existencial. En «La neurofenomenología en la recepción teatral», Miguel Ribagorda Lobera se encarga de indagar en la experiencia subjetiva y en cómo un espectador experimenta y percibe una representación escénica.

El segundo apartado del libro, «Dramaturgias femeninas», recoge seis estudios muy innovadores y curiosos. El primero de ellos, «Aspectos filosóficos en algunas 
puestas en escena de Antígona en el siglo XXI»), de Olivia Nieto Yusta, aborda el mito de Antígona, como símbolo de justicia, dignidad y lucha contra la represión, que se aprecia en tres montajes teatrales actuales, dirigidos por Rubén Ochandino, Miguel de Arco y Helena Pimenta. En «La búsqueda de la trascendencia humana: La guerra según Santa Teresa, de María Folguera, y La tumba de María Zambrano, de Nieves Rodríguez Rodríguez», Pilar Jódar Peinado trata la búsqueda del ser en la sociedad actual. En «Nieves Rodríguez Rodríguez, La tumba de María Zambrano. Pieza poética en su sueño (2016). Ecos de la filosofía zambraniana en el teatro actual», Verónica Orazi hace un análisis de La tumba de María Zambrano, de Nieves Rodríguez Rodríguez, obra en la que se observa la fenomenología del sueño de María Zambrano. En «Walter Benjamin y subjetividad histórica en Los hijos de las nubes, de Lola Blasco», Cristina Ros Berenguer analiza el componente filosófico de Los hijos de las nubes, de Lola Blasco. En «El proyecto comunitario Rebomboris: la ética del cuidado a escena», Ana Prieto Nadal explica el proyecto Rebomboris (2018), que permite una nueva experiencia del «nosotros». En «La filosofía del Teatro Invisible de Matarile Teatro», Ana M. ${ }^{\mathrm{a}}$ Fernández Fernández explica el espectáculo Teatro Invisible, realizado por la compañía Matarile Teatro, en el que el público y las emociones son esenciales en la escena.

El capítulo titulado «Dramaturgias masculinas» contiene nueve estudios que versan sobre dramaturgias españolas y de diferentes ámbitos geográficos. De este modo, en «Filosofía y teatro en las últimas obras de Juan Mayorga: El mago e Intensamente azules», Miguel Ángel Jiménez Aguilar indica que el teatro de Juan Mayorga posee una gran carga filosófica, como se observa en los personajes y en los conflictos planteados en sus obras. En «Muerte del padre y duelo en Inconsolable, monólogo dramático de Javier Gomá», Rafael González-Gosálbez indica que, como ya hiciera Jorge Manrique, el filósofo Javier Gomá transmite la experiencia de la pérdida de su padre en Inconsolable. María Teresa Osuna Osuna, en «Walter Benjamin en Todos los caminos, de Juan Pablo Heras: recuperar en la palabra lo perdido», demuestra la trascendencia que tiene la filosofía de Benjamin en Todos los caminos, de Juan Pablo Heras, en la que se produce una búsqueda de lo eterno en el tiempo. En "It's man devouring man, my dear: Sweeny Todd en Malasia, o la negociación de conflictos éticos a través de adaptaciones escénicas», Camacho Fernández y Tan Elynn analizan la práctica teatral del musical Sweeny Todd, de Stephen Sondheim.

Las figuras de Sócrates, Wittegenstein, Freud y Lewis, o la Biblia en clave humorística y filosófica son analizadas en los artículos que cierran el apartado último, ya que sus doctrinas filosóficas son fundamentales en muchos espectáculos dramáticos del siglo XXI, como muy bien señalan los trabajos «La figura de Sócrates 
en dos obras contemporáneas: Sócrates, el encantador de almas, de Eduardo Rovner y El banquete, de Chema Cardeña», de Nel Diago, «El último filósofo o Wittgenstein: lenguaje y presencia teatral en la poética de Marco Antonio de la Parra», de M. ${ }^{\mathrm{a}}$ Nieves Martínez De Olcoz y Sonia Sánchez Fariña, «Freud y Lewis, tan cerca, tan lejos», de José Gabriel López Antuñano, «La Revelación, de Leo Bassi: proselitismo del ateísmo a través del conocimiento, la imperfección y el humor», de Eva García Ferrón, y «Nietzsche en la boda de Hitler con Eva Braun. Una obra teatral de Hartmut Lange», de Arno Gimber.

En definitiva, todos estos estudios, que conforman el volumen Teatro y Filosofia en los inicios del siglo XXI, manifiestan la trascendencia de la filosofía en las artes escénicas, pues ambas están muy conectadas desde siempre, puesto que el ser humano necesita reflexionar sobre la vida, sobre la muerte, sobre los sentimientos, sobre las experiencias que vive en la sociedad contemporánea... Y es que el teatro refleja inquietudes, anhelos o sentimientos, y en su esencia se halla una fuerte raíz filosófica, que lo hace muy atractivo. Por ello, este libro constituye un enfoque nuevo de la dramaturgia, que no sólo es original, sino que, además, es muy enriquecedor para sus lectores. 